\title{
THE EFFECT OF DRAMA IN EDUCATION TOWARDS THE SUBJECT OF PHYSICAL EDUCATION IN ELEMENTARY SCHOOLS
}

Nick Mavroudis ${ }^{i}$

PhD, School of Physical Education and Sports Science, National and Kapodistrian University of Athens,

Greece

\begin{abstract}
:
This article aims to fill the bibliographic gap concerning the way physical education teachers may apply drama in education in elementary schools. Drama in education is an educational method which, based on movement, speech and expression, aims at the comprehensive development of a child. The application of its techniques may provide new dimensions and perspectives to the teaching of physical education in elementary school.
\end{abstract}

Keywords: drama in education, physical education, social learning, emotional intelligence

\section{Introduction}

Today education as the main driving force of social development is in the center of changes that significantly affect humanity. The uninterrupted movement of products and people, the speed of communication, the development of digital technology as well as the consumer models of values and products which are provided worldwide, tend to make human behavior similar eliminating distances and differences around the world (Bakhtiari \& Shajar, 2006). Nowadays, societies are wide open, materially and mentally, accepting that they are not perfect, while looking forward to discovering unexplored, until now, possibilities. With each future step it is necessary to respond to a different set of opportunities and each time a different set of skills and a special qualification arrangement are invoked (Bauman, 2017). In a society where many people are uncertain of their own lives and every acquired skill is by definition temporary or reversible (Tsoukalas, 2010), education is called upon to redefine its role in relation to the way people coexist and co-create.

i Correspondence: email nikolasm1@hotmail.com 
Physical education as it is connected and influenced by the general purpose of education is called to re-evaluate its role and priorities. In view of the growing social insecurity and its negative effects on the psychosynthesis and prosperity of young people, Kirk (2018) emphasizes the necessity for physical education to put emotional learning at the core of its priorities. Opstoel et al., (2019), based on the UNESCO research, propose personal and social development as the most accepted goal of physical education worldwide, while the Curriculum of the Hellenic Institute of Education Policy (IEP, 2014, p.14) regarding the physical education in elementary school stresses the necessity of "the cultivation of skills, attitudes and behaviors such as self-esteem, critical and creative thinking, positive social behavior, acceptance of others, goal setting, communication", so that children benefit in all areas of the human dimension. In this perspective, physical education must meet its multidimensional role by adopting new forms of group-collaborative learning so that students may identify themselves in terms of their place and action in the postmodern world. Drama in education offers such an option, through which physical education teachers may enrich their teaching by achieving their goals better.

This article tries to fill in the gaps on this issue. Through the recent bibliographic research, it attempts to explore the ways in which physical education teachers may apply drama in education during the elementary school lessons, aiming at the comprehensive development of the personality of young people. That is why it is supposed to be interesting for everyone who is involved in its teaching.

However, before referring to the practical application of drama in education during the physical education class, we will briefly present this educational method in the next chapter. We will also look into its relationship with the physical education.

\section{Drama in education and physical education}

Drama in education is an alternative form of education, which derives its exercises and techniques from drama used in education for pedagogical purposes. As an educational method, drama in education includes exercises and techniques, such as pantomime, improvisation, role play, dramatization, physical expression activities, frozen images, body sculptures, forum theater, playback theater. It also includes activities which develop expressiveness, communication within the group, exercises of concentration, relaxation, breathing, confidence, body coordination, development of rhythmic ability, exercises in pairs, etc. (Alkistis, 2008, 2012).

The teacher uses these techniques, not with the intention to stage a theatrical performance, although this might not be ruled out, but with the purpose of achieving specific pedagogical goals: to provoke the student's active involvement in knowledge, to modify attitude and behavior, to motivate students to think independently and creatively, to better understand themselves and the world around them, to develop skills of communication, cooperation, interpersonal relationships, to derive joy and satisfaction (Bolton, 1998; Chougule, 2015; Elald1 \& Yerliyurt, 2016; Kalidas, 2014; Mavroudis \& Bournelli, 2019; McCaslin, 2006). 
Perhaps the most important part of drama education is the creation of a safe environment, an imaginary world, in which the senses and emotions dominate, and the participants explore ideas through commonly accepted rules, issues, relationships and play roles, overcoming their daily selves (McCaslin, 2006; O'Neill, 1995; Sirisrimangkorn \& Suwanthep, 2013), and without clear boundaries between "actor" and audience, since the student is both a participant and an observer (Somers, 2013). Through movement, interactions, speech and alternation of roles, drama allows the experience to emerge, the creative imagination to develop, it is a place of meeting and exchange of experiences, a place of public dialogue of ourselves with the other. Students, through their identification with a role, try to become the other, to feel like the other, to experience how the other sees things. It is a process that releases consciousness, transforms it and leads to empathy and intercultural communication (Adorno, 1970; Kosti et al., 2015; Mpella \& Evaggelinou, 2018; Papaioannou \& Kontoyanni, 2019; Mavroudis, 2020).

In this context, social skills are naturally developed, due to the need of each student to interact with the other members of the group (Ball, 2012; Mavroudis \& Kontoyanni, 2020). Participants gain a sense of emulation and collective coordinated action, a sense of respect for the rules. The need to continue the game or to complete a dramatization urges students to listen to each other, to exchange information, to manage their disagreements, and to respond to positive behavior. Thus, they are transformed from egocentric beings into personalities capable of sharing everything with others (Giannaris, 2001). At the same time, it ensures for all participants the feeling of belonging to a wider group of people who provide security, purpose, competence and ultimately identity. This feeling is necessary for the development of self-esteem, as no one values themselves positively unless they feel that they belong somewhere (Hefferon, 2000).

The researchers also confirm the important role of physical activities while developing similar skills in a student (Bailey, 2005; Gudas \& Magotsiou, 2009; Mchugh, 2015; Salamuddin \& Harun, 2010; Singer, 2009). Through physical education students are encouraged to develop social relationships, leadership and organizational skills and to evolve a range of positive moral and strong personality traits such as a sense of purpose, determination, responsibility, adherence to rules, cooperation, solidarity. As well as in drama in education, they experience valuable emotional experiences, feel motivated to optimize their emotional reactions, cultivate skills such as self-control, emotional stability, self-esteem and self-perception, self-confidence, and self-respect (Cañabate et al., 2018; Kalina et al., 2018; Moisescu, 2014).

Physical education lessons act as a personality transformer enriching the moral and aesthetic principles of the participants. Students learn specific behavior and acquire adaptation and initiation skills within the group. Moreover, the development of their social skills leads to the reduction of conflicts, to devotion, to reciprocity, to the establishment of friendly relations. Consulting with other people shapes their character and prepares them for the challenges they will face as adults. The social behaviors which students learn during the activities are then available to them and can be used in future contexts of their lives, such as work or interpersonal relationships. That is why physical 
education is also a tool of social transformation (Cañabate et al., 2018; Leisterer \& Jekauc, 2019; Nelson \& Woods, 2007; Sami et al., 2015). Physical education and drama in education set identical goals, the one influences and complements the other, while also the role of drama in the transformation of society and in the development of aesthetic and socio-emotional learning is considered indisputable. Both physical education and drama in education utilize the dynamics of the whole group and have as a characteristic the experiential learning. Makris et al., (2017) point out that experiential learning promotes freedom of expression, creates a closer contact between students and teachers, while students acquire a high level of self-determination and autonomy. Learning is achieved by treating the student as a whole. It includes thoughts, feelings, perceptions and behavior and it is a process of constructing knowledge and not simply transferring it, highlighting all the mental wealth of the participants (Giannouli, 2019).

The physical education teacher is certainly not called to "teach" theaterii, to deal with the acting of the participants. This would require specialized knowledge. The physical expression, the game, is at the core of the drama. Game means movement and through movement learning is achieved effortlessly. The physical education teacher is called to use these elements of drama in order to activate students, to release their imagination and creativity, to socialize them, to develop the psychomotor dimension of their personality (Kouretzis, 2008).

The next chapter presents three (3) indicative 45-minute physical education lesson plans focusing on drama in education, which mainly concern students aged 10-12 years old. However, many of these activities can also be used for younger students. The music should accompany many of the actions described in the following chapter.

\section{The application of drama in education during the physical education lesson}

\section{1st Lesson Plan}

Main Objective: To get to know each other better, to communicate, to cooperate, to trust each another.

\section{A. Group activation}

The circle. Specific objectives: To develop a visual contact, non-verbal communication, cooperation, a sense of acceptance, a sense of space.

Students form a circle holding their hands. Then, students slowly stretch their arms and open their legs, so that their body occupies as much space as possible, creating the largest circle they can make and taking care not to break the ties of their arms. The team then

\footnotetext{
ii Drama is based on the natural ability of man to play, to represent and to focus on the communication between the participants in his/her actions. The theater, on the other hand, is interested in the communication between the performers-actors and the audience. Everyone can participate in the activities of the drama, but the requirements of the theater concern only those who are familiar with its techniques (Bodden, 2006; Idogho, 2013).
} 
creates the smallest circle they can make. Be careful, all students should stand in the perimeter of the circle and no one should be excluded ${ }^{\mathrm{iii}}$.

\section{B. Main subject}

Movements. Specific objectives: To develop the sense of space and the ability to move in space by walking.

The students move within the space walking. They try to cover all the gaps in the space with their presence, without speaking and without coming into physical contact with each other. The students move by changing directions and levels of space (low, medium, high).

Meetings. Specific objectives: To develop active listening, auditory perception, a sense of acceptance through the recognition of similarities which students have with their neighbor.

The students, as they walk, upon every order:

- shake hands with any student they meet,

- one student tells the other what is his/her favorite color,

- what is his/her favorite song,

- talk to each other about how they usually spend their afternoons.

Colombian hypnosis. Specific objectives: To develop observation, self-concentration, readiness, motor coordination, cooperation, confidence and non-verbal communication.

Each student becomes a partner with the student who stands closer and determine who will be the driver. The driver moves in space and changes levels (high-medium-low) and speeds (slow-fast). His/her partner follows him/her with the gaze focused on the driver's palm, always keeping the same distance $(15-20 \mathrm{~cm})$. After that, students change roles.

The animal voices. Specific objectives: Development of cooperation, non-verbal communication, self-perception, creativity, auditory perception, motor expression.

The teacher distributes to each student a piece of paper with the name of an animal to which the student shall transform. Then the students close their eyes and scatter walking within the space. Each student, imitating the voice of his/her animal, should meet his/her partner, because there will be other students in the group who will imitate the same animal. There will be for example two wolves, three hens, two owls, four dogs, two cats, two cows...

The buoys. Specific objectives: Development of kinesthetic perception, acoustic perception of cooperation, responsibility, concentration, trust.

Some students stand in a space indicated to them, one away from the other. These students will be the buoys. Another student is the boat. The boat with his/her eyes closed

\footnotetext{
iii Students check their feet to make the perfect circle: they should be neither inside nor outside the feet of their neighbors. They can confirm the perfection of the circle if they can see the student next to their neighbor without being forced to bend over (Holeva et al., 2019).
} 
should pass between the buoys, without touching them. Each buoy, with a sound he/she produces, informs about its position every time the student-boat goes to fall on it ${ }^{\mathrm{iv}}$.

Sound landscape. Specific objectives: Cultivation of cooperation, coordination, active listening, imagination, creativity, auditory perception.

The class is divided into four (4) groups. Each group stands in a circle and after communicating first, without moving from its position, presents a picture with sounds. The other groups, listening to the sounds, try to understand which image is created. The first group e.g. has as theme: stadium, the second: public market, the third: jungle, while the fourth: big city street. When the first group starts, the others close their eyes to hear and to understand what each group represents in terms of sound. The exercise can be done with a topic that will be chosen by the groups themselves.

\section{Self-reflection - Discussion ${ }^{v}$}

The students gather around a circle and discuss what is happening. Questions can be asked such as: Does anyone want to share with the group thoughts and feelings about the games we played? How did you feel when you closed your eyes? Was there a willingness to work with both, your partner and the other students in the groups? Did you trust your classmates?

\section{2nd Lesson Plan}

Main Objective: To train children in recognizing and expressing emotions.

\section{A. Group activation}

Walking... Specific objectives: To develop the ability to feel the space, motor expression, imagination, emotional intelligence.

Students move trying to fill the gaps within the space and without speaking. They move according to the teacher's instructions: Now walk while you are sad, happy, annoyed by something, anxious, frightened, walk with pride, with courage, while you are thirsty, walk hurriedly making a fuss with your feet, completely silent now.

\section{B. Main subject}

The feelings. Specific objectives: To develop the ability to feel the space, the ability of auditory perception, self-action, imagination, comprehension and physical expression of emotions.

The student move within the space in any way they want, having in mind an emotion which they tell other student they meet. The purpose is to express their feelings to all the students, but also to listen to the feelings of the others. Upon order, students stop moving

\footnotetext{
iv A variation of this exercise is to have another student in the class to verbally guide (e.g. take small steps to the right, walk straight, stay still) the one who tries to pass between the buoys with closed eyes. Buoys in this case do not produce sounds and may consist of objects.

$\checkmark$ The process of reflection is considered very important in experiential activities because it contributes to critical thinking and leads to conscious action (Freire, 2001, 2004). As Edmiston (1993) points out, Vygotsky believes that through reflection, students' thoughts are shaped and become an entity, while at the same time participants explore and organize whatever they have experienced.
} 
and shout their feeling loudly. Then they create a statue with their body that indicates this feeling. Upon every order they create another statue, each time always in relation to the chosen feeling. Upon the last order, they remain still. As the teacher touches each student, the student shouts out his/her feeling loudly.

Separation of groups. Specific objectives: Development of the ability of cooperation, active listening, creativity.

The students are randomly divided into groups of 4-5 people (e.g. in relation to where each students was last time). Each group, after consultation, chooses a feeling and comes up with a frozen image ${ }^{\mathrm{vi}}$ created with the bodies of the team members and always in relation to the feeling that has been chosen.

Group sculpture composition. Specific goals: To develop physical and emotional expression, cooperation, creativity, self-esteem.

Each group presents its frozen image to the other students, who try to understand what the feeling is about and what exactly the image presents. The teacher touches the head of each student in the sculpture, who says what he/she feels and what he/she thinks in relation to the posture of his body in the composition. If any of the students who observes, wants to, he/she can correct the group sculpture, in order to correspond to his/her own perception of how the specific feeling should be dramatised.

\section{Self-Reflection - Discussion}

Students sit in circle and discuss what is happening. Questions can be asked such as: How did you feel about today's experience? Which feeling did you choose and why? What feelings and emotions do you know? Why do we find it difficult to express emotions? Does it benefit us to be able to express them?

\section{3rd Lesson Plan}

Main Objective: To make students to know their body better. To develop the ability of dismantlement of the body.

\section{A. Group activation}

The trembling body. Specific objectives: Activation of the body, to acquaint students with the concept of "dismantlement of body parts".

Students are in a circle. A student's head begins to tremble and then stops. The next student in the circle, adopts this tremor in the head for a while and then transfers it to another part of his body, e.g. to his/her foot. The next student adopts the tremor in the

\footnotetext{
vi Frozen image / Individual sculpture or group sculpture composition: Participants create an image with their bodies individually or in groups, based on a theme or idea. The technique gives the opportunity to the one who creates the image to act selectively by removing anything unnecessary and by focusing on the important thing, while at the same time the spectators practice on the reading of the image. Those who do not participate in the image discuss the created composition. No speech is used and at the first level we are interested in physical activity of students who have difficulty to be exposed. (Avdi \& Chatzigeorgiou, 2007; Boal, 2004; Govas \& Zoniou, 2010).
} 
fool and then moves it to another body part, e.g. to the palm of his hand. This way all students participate in the game until the end of the cycle.

\section{B. Main subject}

Walking... Specific Objectives: To develop body knowledge, motor expression, imagination and motor coordination.

Students move around walking within the space, without coming into physical contact with each other. They transform and walk like zombies, like robots, like drunks, like giants, like dwarves, like grandparents, like puppets.

The fantastic rope. Specific objectives: To develop the ability to know and to dismantle the body, to develop the ability to isolate body parts.

Students walk within the space. A fantastic rope is tied to their left knee and pulls them. The students move within the space with the left knee extended. Then the rope is tied to other parts of their body: to the left index finger, to the nose, to the navel, to the jaw, to the right ankle. The students move accordingly.

The breath. Specific objectives: To acquaint students with diaphragmatic breathing.

Students are lying on their backs on the floor with their palms facing up. They observe their breathing. Then they put one hand on their belly and, breathing through the nose, try to lift it. The goal is to move only their belly and not their chest. Students remove their hands from their belly and observe how they can breathe without moving their chest. A short discussion on the diaphragmatic breathing follows.

Relaxation with speech. Specific objectives: To develop self-concentration, self-perception through the body knowledge, the ability to relax.

Students are lying on their backs on the floor with their palms facing up. They focus and observe their breathing. The teacher with the appropriate tone of voice and accompanied with music (where possible) tries to relax them: "You are lying on a beach. It is summer, the sun burns and leaves a nice feeling on your body. The sun warms your forehead, jaw, whole face. Your head rests on the warm sand and this feeling makes you happy. The neck sinks slowly into the heat of the sand and gradually follows your shoulders, arms, elbows, fingers, back, waist, pelvis. At the same time the sun warms your neck, chest, belly, pelvis, knees, toes. Gradually the whole-body sinks into the nice feeling left by the warm sand. Do not forget to observe your breathing at the same time. Your body feels warm, relaxed and lite".

The tree and the seasons (guided improvisation). Specific objectives. To develop imagination, creativity, kinetic and physical expression, self-perception.

Students are on the floor. They transform into a small seed which is underground. It is winter and the seed feels protected from the cold. It is waiting for the weather to warm up so that it comes to the surface. The sun begins to warm up, spring comes and the seed gradually grows and sprouts through the earth. It becomes a tree that grows, acquires a trunk, leaves and deep roots that give stability and confidence. The tree has branches and flowers that musk. It really enjoys the sun and the gentle breeze of spring. Summer is coming, the tree is growing, its roots are spreading, and it acquires fruits, which weigh 
down its branches. The sun is pleasant, and the wind gently sways the branches. Autumn is coming, the fruits are not anymore on the tree and the leaves begin to fall. First rains begin, the tree enjoys them as it has been suffering since the summer. The air is more intense and cold appears. Winter is coming, the wind is raging, violently shaking the branches of the tree. The tree though is not afraid. It has deep roots and is confident about itself. The snow falls and weighs down its bare branches. It is a heavy winter, but the tree knows how to wait, because it knows that spring will come again.

\section{Self-Reflection-Discussion}

The students sitting around in a circle, discuss their feelings, evaluate their experience, share their impressions. They can talk about whether they relaxed, what made it difficult for them, what impressed them the most.

\section{Conclusion}

In an era when collective action is devalued and individuals are called to value themselves for their own abilities and strengths, only for their own individualistic account (Tsoukalas, 2010), a modern curriculum for elementary school should have a humanitarian orientation. Physical education apart from a pleasant and positive experience can be the trigger for children to embrace values and develop behavior that will allow them to integrate harmoniously into society (IEP, 2014). Drama in education may provide a new dimension to the role of Physical Education in the fluid social reality that people are experiencing today. It can enrich the effort for an education with humanistic priorities with new perspectives, having as a main concern that students should live their lives, in the way they believe it is a worthwhile way of living (Dahlstrom, 2009).

\section{Conflict of Interest Statement}

The author declares no conflict of interest.

\section{About the Author}

Nick Mavroudis teaches Physical Education at the 87th Multicultural Primary School of Athens. He has also studied acting at the Drama School of the National Theatre of Northern Greece. He holds a PhD in Drama in Education from the School of Physical Education and Sports Science, National and Kapodistrian University of Athens.

\section{References}

Adorno, T. (1970). Aesthetic Theory. London: Bloomsbury.

Alkistis (2008). Black Cow, White Cow. Dramatic Art in Education and Interculturalism. Athens: Topos. (in Greek) 
Alkistis (2012). Dramatic Art in Education. Athens: Pedio. (in Greek)

Avdi, A., \& Chatzigeorgiou, M. (2007). The Art of Drama in Education. Athens: Metaichmio. (in Greek)

Bakhtiari, S., \& Shajar, H. (2006). Globalization and education: Challenges and opportunities. International Business E Economics Research Journal, 5(2), 95-100.

Ball, D. (2012). Dramatherapy with children who have been bullied: Anne Banister Award 2010. Dramatherapy, 34(1), 35-46.

Bauman, Z. (2017). Fluid Times. Life in the Age of Modernity. Athens: Metaichmio. (in Greek) Bailey, R. (2005). Evaluating the relationship between physical education, sport and social inclusion, Educational Review, 57(1), 71-90.

Boal, A. (2004). Games for Actors and non-Actors. London: Routledge.

Bodden, L. M. (2006). Developing a Creative Classroom Through Drama Work. The University of Arizona.

Bolton, G. (1998). Acting in Classroom Drama: A Critical Analysis. Birmingham: University of Central England.

Cañabate, D., Martínez, G., Rodríguez, D. \& Colomer, J. (2018). Analysing emotions and social skills in physical education, Sustainability, 10, 1-8.

Chougule, R. ( 2015). Methods of teaching drama. Literary Endeavour, 6(4), 88-90.

Dahlstrom L. (2009). Education in a post-neoliberal era: A promising future for the global south? Power and Education, 1(2), 167-177.

Edmiston, B. (1993). Structuring drama for reflection and learning: A teacher-researcher study. Youth Theatre Journal, 7, 3-11.

Elaldı, Ş., \& Yerliyurt, N. S. (2016). The efficacy of drama in field experience: A qualitative study using maxqda. Journal of Education and Learning, 6, 10-26.

Giannaris, G. (2001). Theatrical Education and Play. Athens: Grigori. (in Greek)

Giannouli, B. (2019). Theater in education and principles of experiential learning and critical pedagogy - The framework of a training program for sensitive poetry in matters of approaching the "other". In: Holeva, N. (ed.), What If it was You? Athens: Panhellenic Network for Theater in Education, 68-77. (in Greek)

Govas, N., \& Zoniou, C. (2010). Theatrical Pedagogical Programs with Forum Theater Techniques. Athens: Panhellenic Network for Theater in Education \& Osmosis Center for Arts \& Intercultural Education. (in Greek)

Goudas, M., \& Magotsiou, E. (2009). The effects of a cooperative physical education program on students' social skills. Journal of Applied Sport Psychology, 21, 356-364.

Holeva, N., Karaviti, J., \& Govas, N. (2019): Training of teachers with techniques of theater, Educational Drama and experiential learning on human rights and refugees. In: Holeva, N. (ed.), What If it was You? Athens: Panhellenic Network for Theater in Education, 68-77. (in Greek)

Hefferon, C. (2000). Process drama: Its effect on self-esteem and inclusion of primary fifth class boys and girls. Dissertation (M. Ed) --St. Patrick's College.

Freire, P. (2001). Pedagogy of Freedom. Lanham: Rowman \& Littlefield.

Freire, P. (2004). Pedagogy of Hope. New York: Continuum International Publishing. 
IEP (2014). Physical Education Curriculum for Primary Education. Athens: ҮPEPU

Idogho, J. A. (2013). Drama/theatre in education and theatre as an academic discipline: A question of nomenclature, techniques and effects. An International Journal of Arts and Humanities, 2(3), 228-248.

Kalidas, C. (2014). Drama: A tool for learning. Procedia - Social and Behavioral Sciences, 123, 444-449.

Kalina, I., Golubev, A.I., \& Aidarov, R.A. (2018). The role of physical education in developing students' social and psychological qualities of a personality, SHS Web of Conferences 50, 1-4.

Kirk D. (2010). The practice of physical education and the social construction of aims. In: Bailey, R. (ed.) Physical Education for Learning: A Guide for Secondary Schools. London/New York: Continuum, 15-25.

Kosti, K., Kondoyianni, A., \& Tsiaras, A. (2015). Fostering historical empathy through drama in education: A pilot study on secondary school students in Greece. Drama Research, 6(1), 1-22.

Kouretzis, L. (2008). The Theatrical Game and its Dimensions. Athens: Traveler. (in Greek)

Leisterer, S., \& Jekauc, D. (2019). Students' emotional experience in physical education-A qualitative study for new theoretical insights. Sports, 7(1), 2-15.

Makris, A., Georgiadis, K., \& Mountakis, K. (2017). The pedagogical value of Olympic education. Ysplix. Scientific Journal of Physical Education, 4, 1-21. (in Greek)

Mavroudis, N. (2020). Drama in education as an educational tool for the management of cultural diversity in primary schools. International Journal of Learning and Development, 10(4), 95-108.

Mavroudis, N., \& Bournelli, P. (2019). The contribution of drama in education to the development of skills improving the interpersonal relations of multicultural classroom students. Journal of Educational Issues, 5(2), 42-57.

Mavroudis, N. \& Kondoyanni, A. (2020). Drama in education: It's effectiveness in acceptance of racial diversity in a multicultural classroom. Scholars Journal of Arts, Humanities and Social Sciences, 8, 482-488.

McCaslin, N. (2006). Creative Drama in The Classroom and Beyond. Boston: Allyn \& Bacon.

Mchugh, E. (2015). Going 'beyond the physical': Social skills and physical education. Journal of Physical Education, Recreation E Dance, 66(4), 18-21.

Moisescu, P. (2014). The role of physical education has social integration of children dominated computer. Procedia - Social and Behavioral Sciences, 116, 4159-4163.

Mpella, M. \& Evaggelinou, C. (2018). Does theatrical play promote development of social skills in students with autism? A systematic review of the methods and measures employed in the literature. Preschool E Primary Education, 6(2), 96-118.

Nelson, N.M., \& Woods, C.B. (2007). Engineering children's physical activity: Making active choices easy. Municipal Engineer, 160(2), 103-109.

O' Neill, C. (1995). Drama Worlds - A Framework for Process Drama. Portsmouth: Heineman. 
Opstoel, K., Chapelle, L., Prins, F., De Meester, A., Haerens, L., Tartwijk, J., \& Martelaer, K. (2019). Personal and social development in physical education and sports: A review study. European Physical Education Review, 10, 1-19.

Papaioannou, T., \& Kondoyianni, A. (2019). Promoting the acceptance of the 'other' through drama in education. Yaratıc Drama Dergisi, 14(2), 309-320.

Salamuddin, N. \& Harunb, M. (2010). Facilitating the process of learning social skills through humanistic physical education. Procedia Social and Behavioral Sciences, 9, 223-227.

Sami, S., Mahmoudi, S., \& Aghaei, S. (2015). Social development of students participating in physical activity and computer games. Annals of Applied Sport Science, 3, 51-56.

Singer, J. (2009). Researching imaginative play and adult consciousness: Implications for daily and literary creativity. Psychology of Aesthetics, Creativity, and the Arts, 3, 190199.

Sirisrimangkorn, L., \& Suwanthep, J. (2013). The effects of integrated drama-based role play and student teams achievement division (STAD) on Students' speaking skills and affective involvement. Scenario, 2, 64-78.

Somers, J. (2013). Drama in the Curriculum. London: Cassell.

Tsoukalas, K. (2010). The Invention of Otherness. "Identities" and "Differences" in the Age of Globalization. Athens: Kastaniotis. (in Greek). 

be applied to their work. Under the terms of this license, no permission is required from the author(s) or publisher for members of the community to copy, distribute, transmit or adapt the article content, providing a proper, prominent and unambiguous attribution to the authors in a manner that makes clear that the materials are being reused under permission of a Creative Commons License. Views, opinions and conclusions expressed in this research article are views, opinions and conclusions of the author(s). Open Access Publishing Group and European Journal of Physical Education and Sport Science shall not be responsible or answerable for any loss, damage or liability caused in relation to/arising out of conflict of interests, copyright violations and inappropriate or inaccurate use of any kind content related or integrated on the research work. All the published works are meeting the Open Access Publishing requirements and can be freely accessed, shared, modified, distributed and used in educational, commercial and non-commercial purposes under a Creative Commons attribution 4.0 International License (CC BY 4.0). 